\title{
Short Article \\ SYDENHAM, LOCKE AND SYDENHAM'S DE PESTE SIVE FEBRE PESTILENTIALI
}

by

\section{GUY MEYNELL *}

The second edition of Sydenham's Methodus curandifebres (1668) had an added chapter on plague and its treatment which he reprinted virtually unchanged in his later book, Observationes medicae (1676, and subsequent editions). This chapter has an interesting paragraph which is unique in Sydenham's work: it mentions the opinions of other writers. Its origin appears to lie in Sydenham's association with John Locke at the time the paragraph was written.

The paragraph in question comes on pp. 191-4 of the Methodus where Sydenham discusses the place of venesection in the treatment of plague. ${ }^{1}$ He begins by disagreeing with Diemerbroeck's opinion that bleeding is harmful and then goes on to support his conclusion by giving the names of thirteen authors: "Ludovicus Mercatus, Joannes Costaeus. Nicolaus Massa, Ludovicus Septalius, Trincavellius, Forestus, Mercurialis, Altomarus, Paschalius, Andernachus, Pereda, Zacutus Lusitanus, Fonseca, aliique." He ends the paragraph with a long quotation from Leonardus Botallus, testifying to the value of bleeding.

Diemerbroeck's text refers to numerous other authors and often gives references to their books. What stands out is that the thirteen authors listed by Sydenham are also listed one after another as a group by Diemerbroeck, though not in the same order, plus "Ianus Antonius Saracenus" and "Paulus Mongius" who may be Sydenham's "others" (aliique). Moreover, Sydenham uses the same forms for the names: e.g. "Nicolaus Massa" rather than "Massa"; and "Forestus" rather than "Petrus Forestus". It seems therefore that Diemerbroeck's book was the source of Sydenham's references.

Sydenham himself is not likely to have owned the book. He is not known to have possessed a library and, indeed, he gives the impression of not being over-much concerned with anyone's experience but his own. The exact opposite was true of Locke, who was certainly acquainted with Sydenham by this time because he contributed a poem to the second edition of the Methodus. Throughout his life Locke kept a series of commonplace books crammed with notes on medicine, theology and other subjects that interested him. In one of them dated " 25 Feb 1659" on the front endpaper, the latest books noted are Willis' Cerebri anatome, 1664 (see p. 81) and Timaeus' Epistolae et consilia, 1665 (see p. 45). ${ }^{2}$ On

* G. G. Meynell, Haven House, Granville Road, St Margaret's Bay, Dover, CT15 6DR.

\footnotetext{
' Paragraphs II. 2.26-28 in Swan's edition of Sydenham's collected works (London, 1742) and in many subsequent editions.

2 British Library, Additional MS. 32,554.
} 
p. 61 , the title and imprint of Diemerbroeck's book are given a note to themselves, ${ }^{3}$ and more notes from it follow on pp. 128, 150 and 177. Whether Locke actually owned the book when Sydenham wrote the second edition of the Methodus in 1667-68 is impossible to say but a book by Diemerbroeck was in Locke's library at Christ Church, Oxford, in July 1681 and this particular edition is listed in his catalogue of 1689-91. ${ }^{4}$

This is not to say that Sydenham merely copied the names of these authors from Diemerbroeck without reading their work. He may have done so but, equally, Sydenham may have read most of them in Locke's library, which includes no less than eight of the fifteen authors that he quotes, as well as Saracenus' edition of Dioscorides' Opera (see Table). The remainder he may have read in encyclopaedic works in Locke's possession, like Sennert's Opera omnia which incidentally discuss Trincavellius, Fonseca and Massa. ${ }^{5}$ The only known draft of this chapter on plague is in Sydenham's writing but represents no more than a fraction of its final length and this paragraph on venesection is absent. ${ }^{6}$

Table: AUTHORS QUOTED BY SYDENHAM WHOSE BOOKS WERE IN LOCKE'S LIBRARY

\begin{tabular}{|c|c|c|c|}
\hline Author" & Title & Imprint & H. \& L. ${ }^{h}$ \\
\hline Diemerbroeck (I. de) & Tractatus de peste & Arnheim, 1646 & 962 \\
\hline Mercado (L. de) & Opera omnia. Lib. VII, p. 455 & Frankfurt, 1620 & $1966 b$ \\
\hline Settala (L.) & Animadversionum. Lib. V, para. 32-35 & Dordrecht, 1650 & 2618 \\
\hline Forestus (P.) & Observationum [etc.] & Rouen, 1653 & 1155 \\
\hline \multicolumn{4}{|l|}{ Altomare (D. A.) } \\
\hline see [P. Salius Diversus] & De febre pestilenti [etc.] & Harderwijk, 1656 & $2534 a$ \\
\hline Paschalis (P.) & Praxis ... de febribus & Leiden, 1631 & $2226 a$ \\
\hline Zacuto (A. ben S.) & Praxis medica admiranda & Lyons, 1637 & 3195 \\
\hline $\begin{array}{l}\text { Botallus (L.) } \\
\text { see also: }\end{array}$ & Opera omnia. Cap. VII. & Leiden, 1660 & 399 \\
\hline Dioscorides & Opera, ed. Saracenus & Frankfurt, 1598 & 973 \\
\hline Sennert & Opera omnia & Lyons, 1656 & 2617 \\
\hline
\end{tabular}

a Spelt as in the British Library Catalogue.

${ }^{b}$ Entry number in Harrison and Laslett (note 4).

That this paragraph is the only one in all of Sydenham's books to include other authors by name is explicable by the circumstances of Locke's life. Sydenham had lived in London since 1655 but Locke only moved there from Oxford in the summer of 1667 in order to work for Lord Ashley. ${ }^{7}$ He and Sydenham probably met for the first time in 1667; that is, in the year after the publication of the first edition of the Methodus. Its four existing chapters were not revised for the second edition: the new fifth chapter on plague and Locke's poem were simply added at the end. It is not farfetched to suggest that, at about the time they first met, Locke knew that Sydenham was contemplating a new chapter on plague and brought

\footnotetext{
3 "Diemerbroeck: Isbrandus de Diemerbroeck de peste $4^{\circ}$ Arenaci [Arnheim] 1646".

${ }^{4}$ J. Harrison, and P. Laslett, The library of John Locke, Oxford Bibliographical Society, 1965, pp. 123, 271. The corresponding catalogue entries are shown here as "H. \& L. 962" etc.

${ }^{5}$ See De febribus. Lib. Iv, De peste, especially c. VI and VII.

' G. G. Meynell, Thomas Sydenham's Observationes Medicae (London, 1676) and his Medical Observations (Manuscript 572 of the Royal College of Physicians of London). With new transcripts of related Locke MSS. in the Bodleian Library, Folkestone, Winterdown Books, 1991, pp. 33-45, 178.

${ }^{7}$ G. G. Meynell, Materials for a biography of Dr. Thomas Sydenham, Folkestone, Winterdown Books, 1988, pp. 18, 26-7.
} 


\section{Guy Meynell}

Diemerbroeck to his attention. Sydenham's next book was the first edition of Observationes medicae, published in 1676 , but by that time, Locke was occupied with far more than medicine. He was seeing patients up to September $1670,{ }^{8}$ but his shorthand transcripts of the medical essays which he wrote with Sydenham end with the epidemics of 1670.9 Not only was Locke occupied by his work for Ashley, but he was living in France in 1675-77 and had begun the drafts of books on economics and philosophy that were to be published decades later. ${ }^{10}$

${ }^{8}$ British Library, Additional MS. 5,714.

${ }^{9}$ Meynell, 1991, op. cit., note 5 above, pp. 6, 8-9.

1" For example, "Some of $y^{\mathrm{e}}$ Consequences $y^{\prime}$ are like to follow upon Lessening of Interest to 4. Per Cent", 1668 , and "De Intellectu humano 1671", in P. Long, A summary catalogue of the Lovelace Collection of the papers of John Locke in the Bodleian Library, Oxford, Bodleian Library, 1959, pp. 30, 35. 